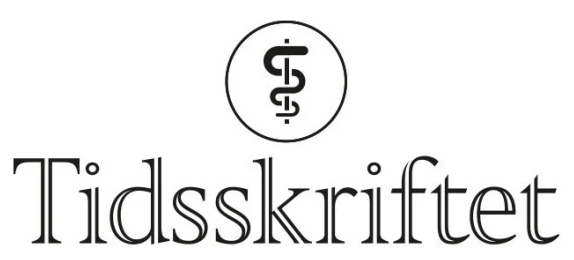

DEN NORSKE LEGEFORENING

\title{
Komplikasjoner og dødelighet blant pasienter innlagt med covid-19
}

ORIGINALARTIKKEL

\section{HÅKON IHLE-HANSEN}

haaihl@vestreviken.no

Seksjon for geriatri, slag og rehabilitering

Medisinsk avdeling

Vestre Viken, Bærum sykehus

og

Forskningsavdelingen

Vestre Viken, Bærum sykehus

Han har bidratt med design og drift av studien, datainnsamling, idé til og utforming av

manuskriptet, litteraturs $\emptyset \mathrm{k}$ og analyse og tolkning av data.

Håkon Ihle-Hansen er ph.d., konstituert overlege og forsker.

Forfatteren har fylt ut ICMJE-skjemaet og oppgir ingen interessekonflikter.

\section{TRYGVE BERGE}

Medisinsk avdeling

Vestre Viken, Bærum sykehus

og

Forskningsavdelingen

Vestre Viken, Bærum sykehus

Han har bidratt med utforming av manuskriptet, litteraturs $ø \mathrm{k}$ og tolkning av data.

Trygve Berge er ph.d., lege i spesialisering og forsker.

Forfatteren har fylt ut ICMJE-skjemaet og oppgir ingen interessekonflikter.

\section{PER ERIK ERN $\varnothing$}

Intensivseksjonen

Avdeling for anestesi, intensiv, operasjon og akuttmottak

Vestre Viken, Bærum sykehus

Han har bidratt med utforming av manuskriptet og analyse og tolkning av data.

Per Erik Ernø er spesialist i anestesiologi og seksjonsoverlege.

Forfatteren har fylt ut ICMJE-skjemaet og oppgir ingen interessekonflikter.

\section{ELSE JOHANNE RØNNING}

Infeksjonsmedisinsk seksjon

Medisinsk avdeling

Vestre Viken, Bærum sykehus

Hun har bidratt med datainnsamling og revisjon av manus.

Else Johanne Rønning er spesialist i indremedisin og i infeksjonssykdommer og seksjonsoverlege.

Forfatteren har fylt ut ICMJE-skjemaet og oppgir ingen interessekonflikter. 
Infeksjonsmedisinsk seksjon

Medisinsk avdeling

Vestre Viken, Bærum sykehus

Han har bidratt med datainnsamling og revisjon av manus.

Jan Svendsen er spesialist i indremedisin og i infeksjonssykdommer og overlege.

Forfatteren har fylt ut ICMJE-skjemaet og oppgir ingen interessekonflikter.

\section{TALE NORBYE WIEN}

Seksjon for nyremedisin

Medisinsk avdeling

Vestre Viken, Bærum sykehus

Hun har bidratt med datagjennomgang og revisjon av manus.

Tale Norbye Wien er ph.d., spesialist i indremedisin og i nyresykommer, overlege og forsker.

Forfatteren har fylt ut ICMJE-skjemaet og oppgir ingen interessekonflikter.

\section{ANDERS TVEITA}

Medisinsk avdeling

Vestre Viken, Bærum sykehus

Han har bidratt med datainnsamling og revisjon av manus.

Anders Tveita er ph.d. og lege i spesialisering.

Forfatteren har fylt ut ICMJE-skjemaet og oppgir ingen interessekonflikter.

\section{ELIZABETH LYSTER ANDERSEN}

Medisinsk avdeling

Vestre Viken, Bærum sykehus

og

Forskningsavdelingen

Vestre Viken, Bærum sykehus

Hun har bidratt med analyse, utforming av database og revisjon av manus.

Elizabeth Lyster Andersen er lege i spesialisering og stipendiat.

Forfatteren har fylt ut ICMJE-skjemaet og oppgir ingen interessekonflikter.

\section{MONICA THALLINGER}

Avdeling for anestesi, intensiv, operasjon og akuttmottak

Vestre Viken, Bærum sykehus

Hun har bidratt med utarbeiding og revisjon av manus.

Monica Thallinger er ph.d., spesialist i barnesykdommer og lege i spesialisering i anestesiologi.

Forfatteren har fylt ut ICMJE-skjemaet og oppgir ingen interessekonflikter.

\section{ARNLJOT TVEIT}

Forskningsavdelingen

Vestre Viken, Bærum sykehus

og

Institutt for klinisk medisin

Universitetet i Oslo

Han har bidratt med tolkning av data og utforming av manus.

Arnljot Tveit er avdelingssjef og professor II.

Forfatteren har fylt ut ICMJE-skjemaet og oppgir ingen interessekonflikter.

\section{MARIUS MYRSTAD}

Seksjon for geriatri, slag og rehabilitering

Medisinsk avdeling

Vestre Viken, Bærum sykehus

og

Forskningsavdelingen

Vestre Viken, Bærum sykehus

Han har bidratt med design og drift av studien, datainnsamling, idé til og utforming av

manuskriptet, litteraturs $\varnothing \mathrm{k}$ og analyse og tolkning av data.

Marius Myrstad er ph.d., spesialist i indremedisin og i geriatri, overlege og forsker.

Forfatteren har fylt ut ICMJE-skjemaet og oppgir ingen interessekonflikter. 


\section{BAKGRUNN}

Sykdomsforløp, komplikasjoner og sykehusdødelighet blant pasienter med covid-19 innlagt ved norske sykehus er lite beskrevet. Formålet med denne studien var å kartlegge pasienter med covid-19 innlagt ved et lokalsykehus.

\section{MATERIALE OG METODE}

Dataene er hentet fra en prospektiv observasjonell kvalitetsstudie av alle pasienter innlagt med covid-19 på Bærum sykehus siden starten av koronavirusutbruddet.

\section{RESULTATER}

I alt 73 pasienter med covid-19 innlagt i perioden 9.3.2020-7.5.2020 ble inkludert. Gjennomsnittsalderen var 67,9 år, og 43 pasienter (59\%) var menn. Gjennomsnittlig antall liggedøgn på sykehus var 10,1. I alt hadde 19 pasienter (26\%) et svært alvorlig forløp, og 14 (19\%) døde under sykehusoppholdet. Gjennomsnittsalderen blant pasientene som døde, var 79,5 år. Totalt 49 pasienter (67\%) hadde hypoksemi og behov for oksygenbehandling i gjennomsnittlig 10,1 dager. Av disse fikk 9 pasienter invasiv respirasjonsstøtte i median 18 dager. Symptomer på delirium forekom hos 26 pasienter (36\%) og var den hyppigste ikkerespiratoriske komplikasjonen.

\section{FORTOLKNING}

De fleste pasientene innlagt på sykehus med covid-19 hadde behov for langvarig oksygenbehandling, og det var høy forekomst av alvorlige komplikasjoner.

\section{HOVEDFUNN}

De fleste pasientene innlagt på Bærum sykehus med covid-19 de første to månedene av utbruddet hadde behov for langvarig oksygenbehandling.

Én av fem pasienter innlagt på sykehuset med covid-19 døde under oppholdet.

De fleste pasientene som døde i løpet av sykehusoppholdet, var over 75 år og ble ikke behandlet med respirator.

Én av tre pasienter hadde symptomer på delirium i løpet av sykehusoppholdet, og dette var den vanligste ikke-respiratoriske komplikasjonen.

Koronaviruset sars-CoV-2 ble første gang oppdaget i Kina i desember 2019 og har forårsaket en verdensomspennende pandemi $(\underline{1}, \underline{2})$. Viruset gir influensalignende sykdom med stor variasjon i klinisk manifestasjon. Flertallet har et mildt til moderat sykdomsforløp, og trolig har mindre enn $5 \%$ av alle smittede behov for sykehusinnleggelse (3). Ifølge Folkehelseinstituttets modelleringer anslås 10-20 \% av innlagte pasienter i norske sykehus å ha behov for intensivbehandling (3).

De fleste pasientene som er innlagt på sykehus med covid-19, har redusert allmenntilstand og symptomer fra luftveiene (4-4-6) . Et mindretall har symptomer som manglende smaks- og luktesans, magesmerter eller funksjonssvikt (7-9.). Noen pasienter innlegges etter å ha blitt akutt forvirret, mens andre opplever forvirring i løpet av sykehusoppholdet (7.). Delirium er en hyppig komplikasjon ved akutt sykdom, og forekomsten øker med alder. Én av tre eldre pasienter innlagt på medisinske avdelinger har delirium - infeksjoner er blant de vanligste utløsende årsakene - og delirium er svært vanlig hos intensivpasienter $(\underline{10}, \underline{11})$. Delirium er en alvorlig tilstand som er forbundet med økt dødelighet i andre

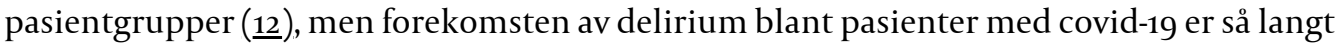
vi kjenner til, ikke undersøkt tidligere. 
Det er i internasjonale studier rapportert om høy forekomst av venøs tromboembolisme og hjerneslag ved covid-19 $(\underline{13}, 14$.). Superinfeksjoner er en vanlig komplikasjon med betydning for prognosen i andre grupper av infeksjonspasienter som behandles på sykehus (15). Forekomst av disse komplikasjonene samt andel pasienter med behov for oksygenbehandling, varighet av hypoksemi og sykehusdødelighet er ikke beskrevet blant norske pasienter med covid-19. Nasjonale forskjeller i befolkningens sosiale forhold, sykelighet og helsetilbud gjør at norske data er av stor betydning.

Vi har tidligere presentert symptomer før innleggelse og kliniske funn ved innkomst hos de 42 første pasientene innlagt med covid-19 ved vårt sykehus (5). Samme kohort er nå utvidet med flere pasienter, og i denne artikkelen presenteres primært sykdomsforløp, komplikasjoner og utfall. Ettersom alder ser ut til å være en viktig prognostisk faktor ved covid-19 $(4, \underline{16})$, har vi undersøkt forekomst av komplikasjoner og dødelighet i ulike aldersgrupper.

\section{Materiale og metode}

Dette er en prospektiv observasjonell kvalitetsstudie gjennomført ved Bærum sykehus i Vestre Viken helseforetak. Metode, karakteristika, symptomer og kliniske funn ved innkomst for de 42 første pasientene er beskrevet tidligere (5). Bærum sykehus er lokalsykehus for cirka 190 ooo mennesker (17.). Medisinsk avdeling har vanligvis 92 senger, og intensivavdelingen er til vanlig bemannet for 6 pasienter med behov for invasiv respirasjonsstøtte.

Første pasient med covid-19 ble innlagt 9.3.2020. Alle pasienter med påvist sars-CoV-2 som var innlagt og utskrevet til og med 7.5.2020, ble inkludert i studien. Alle data ble registrert fortløpende av første- og sisteforfatter ved journalgjennomgang. Ved reinnleggelser ble observasjoner fra hovedoppholdet benyttet.

Som beskrevet tidligere, beregnet vi Charlson Comorbidity Index (CCI) for å beskrive komorbiditet (18), og brukte Clinical Frailty Scale (CFS) (199) til å beskrive skrøpelighet og funksjonsnivå to uker forut for sykdomsdebut (5).

Vi undersøkte forekomst av følgende funn og komplikasjoner: Hypoksemi, akutt forvirring før innleggelse og delirium under sykehusoppholdet, lungeembolisme og dyp venetrombose, kardial påvirkning, hjerneslag, nyresvikt og superinfeksjoner.

Hypoksemi ble definert som behov for oksygenbehandling $\left(\mathrm{SpO}_{2} \leq 93 \% \mathrm{i}\right.$ romluft). Akutt forvirring før innleggelse ble definert som anamnestiske opplysninger om forvirring dokumentert i innkomstjournal. Delirium ble diagnostisert ved gjennomgang av pasientjournaler i henhold til Diagnostic and Statistical Manual of Mental Disorders (DSM-5) (20). Første- og sisteforfatter vurderte dette uavhengig av hverandre, og diagnosene ble stilt etter diskusjon i tilfeller hvor første vurdering var ulik. Tilfeller hvor vi fant dokumentasjon av alle diagnostiske kriterier, ble klassifisert som sikkert delirium. Tilfeller hvor det forelå en akutt endring sammenlignet med pasientens habituelle tilstand og symptomer på delirium, men hvor ikke alle DSM-5-kriteriene var sikkert oppfylt, ble klassifisert som subsyndromalt delirium $(\underline{21}, \underline{22})$.

Lungeembolisme og dyp venetrombose ble påvist ved henholdsvis CT-angiografi og ultralydundersøkelse gjort på klinisk indikasjon. Pasienter innlagt med covid-19 fikk rutinemessig tromboseprofylakse. Kardial påvirkning inkluderte hjerteinfarkt og arytmier. Atrieflimmer ble definert som komplikasjon hos pasienter uten kjent atrieflimmer. Både atrieflimmer og hjerteinfarkt ble definert i henhold til europeiske retningslinjer (233,24).

Hjerneslag ble definert som et nevrologisk utfall tilskrevet en akutt fokal skade i sentralnervesystemet av antatt vaskulær årsak, bekreftet ved bildediagnostikk (25). 
Akutt nyresvikt ble definert som nyreskade eller svikt i henhold til RIFLE-kriteriene (Risk of renal dysfunction, Injury to the kidney, Failure of kidney function, Loss of kidney function and Endstage kidney disease) (므). Vi definerte superinfeksjon som kliniske tegn på superinfeksjon, klinisk og biokjemisk respons på antibiotika eller positiv mikrobiologisk test. Laboratorie-, mikrobiologiske og radiografiske undersøkelser ble utført på klinisk indikasjon.

Vi definerte sykehusdødelighet som andel døde under sykehusoppholdet, relatert eller ikke relatert til infeksjon med sars-CoV-2. Svært alvorlig forløp ble definert som død under sykehusoppholdet, behandling i intensivavdeling eller behandling i intermediærenhet (ikke-invasiv respirasjonsstøtte).

ETIKK

Studien er godkjent av personvernombudet i Vestre Viken helseforetak (20/02772-1). Ettersom dette er en kvalitetsstudie uten intervensjon, og kun rutinemessig innsamlede kliniske data ble brukt, ble kravet om informert samtykke frafalt. Et brev med informasjon om studien og den enkeltes rett til å reservere seg ble sendt per post til alle pasienter, slik at pasientene fikk muligheten til å trekke seg fra studien.

\section{STATISTISKE METODER}

Vi registrerte alle data i EpiData versjon 4.4.3.1 (EpiData Association, Odense, Danmark). Kontinuerlige variabler presenteres som gjennomsnitt og median med spredning, og kategoriske variabler som antall og prosent (\%). Studiens omfang var ukjent på forhånd, det ble ikke definert konkrete hypoteser før oppstart, og en rekke variabler er undersøkt. Tallmaterialet er relativt lite, og muligheten til å sammenligne subgrupper av pasienter er begrenset. Vi har derfor valgt å presentere rent deskriptive data uten statistiske tester. Data ble bearbeidet i SPSS versjon 25.o (IBM, Armonk, NY, USA).

\section{Resultater}

Første pasient med covid-19 ble innlagt på Bærum sykehus 9.3.2020. I løpet av utbruddets første 6o dager, til og med 7.5.2020, var 76 pasienter innlagt (figur 1). På det meste var 24 pasienter innlagt. To pasienter som var innlagt for andre tilstander, og én pasient som fortsatt var innlagt per 7.5.2020, ble ekskludert fra den videre analysen.

Intensivavdeling Infeksjonsmedisinsk sengepost $\square$ Nye pasienter

Antall pasienter

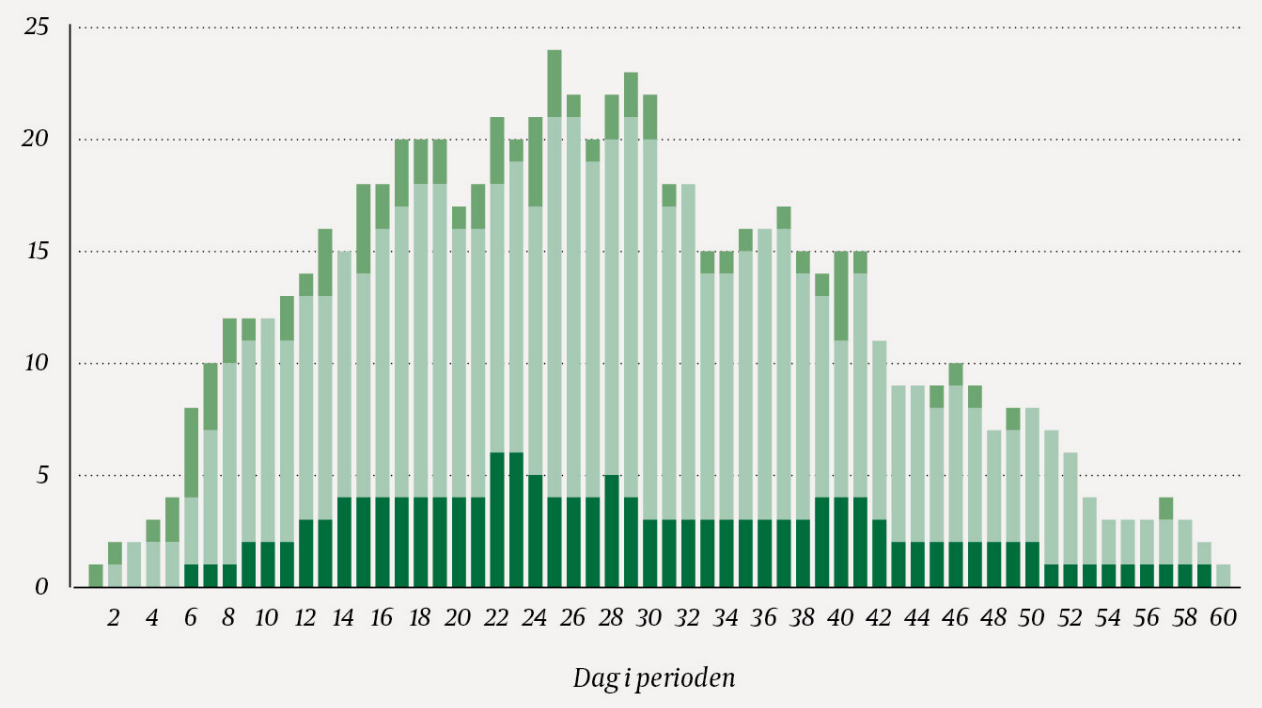

Figur 1 Antall pasienter på intensivavdeling, antall pasienter på infeksjonsmedisinsk sengepost og antall nye pasienter innlagt ved Bærum sykehus per dag i løpet av de første 6o 
dagene av covid-19-utbruddet fra 9.3.2020 til 7.5.2020, $\mathrm{n}=76$. Hver søyle framstiller totalt antall innlagte pasienter med covid-19 per dag i perioden.

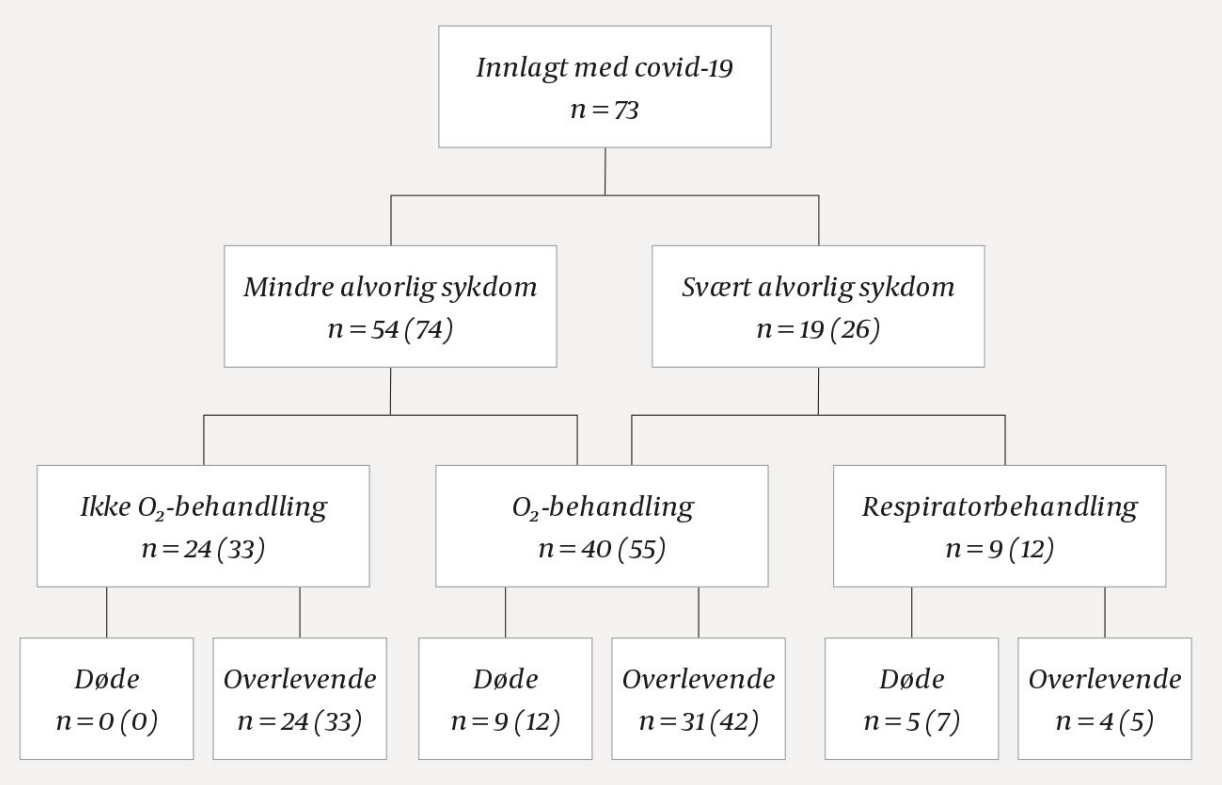

Figur 2 Flytdiagram av studiepopulasjonen. Tallene i parentes angir prosentandel av alle inkluderte pasienter $(\mathrm{n}=73)$.

Gjennomsnittsalder ved innleggelse var 67,9 år (median 71, spredning 30-95), 40 pasienter (55\%) var 70 år eller eldre, og 43 (59\%) var menn. Gjennomsnittlig antall døgn innlagt på sykehus var 10,1 (median 9, spredning 2-39). Fem pasienter ble reinnlagt $\mathrm{i}$ observasjonsperioden. Gjennomsnittlig CFS-skår var 3,o (median 2, spredning 1-7), og 19 pasienter (26\%) var skrøpelige (CFS skår $\geq 5$ ). I alt 19 pasienter (26\%) hadde et svært alvorlig forløp, hvorav 14 (19\%) døde under sykehusoppholdet (figur 2). Antallet døde var to blant pasienter yngre enn 70 år (dødelighet $6 \%$ ), fem (21\%) blant pasienter i gruppen 70-79 år og syv (44\%) blant pasienter som var 80 år eller eldre (figur 3). Gjennomsnittsalderen blant de som døde, var 79,5 år. Fem pasienter døde etter langvarig intensivbehandling, fire av disse var eldre enn 75 år. Hos de andre ni pasientene som døde, ble respiratorbehandling vurdert til ikke å være aktuelt. Gjennomsnittsalderen blant disse ni var 81,4 år, og gjennomsnittlig CFS-skår var 5,3 (median 5, spredning 2-7). 


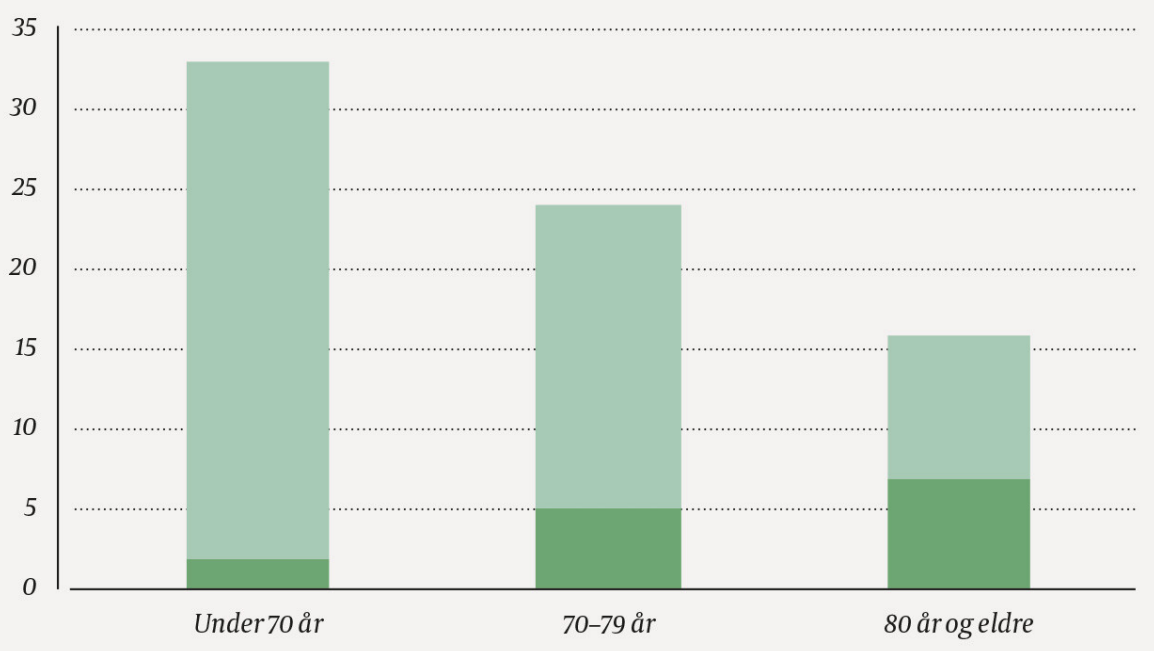

Figur 3 Antall døde og overlevende per aldersgruppe blant pasienter innlagt på Bærum sykehus med covid-19 i perioden 9.3.2020-7.5.2020, $\mathrm{n}=73$.

Hypoksemi var den hyppigste komplikasjonen, og delirium var den hyppigste ikkerespiratoriske komplikasjonen. Totalt 49 (67\%) pasienter hadde hypoksemi og fikk oksygenbehandling i gjennomsnittlig 10,1 dager (median 9, spredning 1-31). Ni av disse fikk invasiv respirasjonsstøtte i gjennomsnittlig 16 dager (median 18, spredning 2-25), hvorav én ble overflyttet til annet sykehus for videre respiratorbehandling. Tre av pasientene med hypoksemi ble behandlet med ikke-invasiv respirasjonsstøtte. Tabell 1 viser utvalgte karakteristika, komplikasjoner, behandling, laboratorieverdier og forløp hos tre grupper: pasienter uten behov for oksygenbehandling, pasienter behandlet med oksygen og pasienter behandlet med invasiv respirasjonsstøtte.

\section{Tabell 1}

Utvalgte karakteristika, komplikasjoner, behandling, laboratorieverdier og forløp hos pasienter innlagt på Bærum sykehus med covid-19 i perioden 9.3.2020-7.5.2020, $\mathrm{n}=73$. Gjennomsnitt (median; spredning) dersom annet ikke er angitt. (FEU = fibrinogenekvivalente enheter. NT-proBNP = N-terminalt pro-B-type natriuretisk peptid.)

\begin{tabular}{|lrrr|}
\hline & \multicolumn{1}{l}{$\begin{array}{l}\text { Ikke } \\
\text { oksygenbehandlet } \\
(\mathbf{n = 2 4})\end{array}$} & $\begin{array}{l}\text { Oksygenbehandlet } \\
(\mathbf{n = 4 0})\end{array}$ & $\begin{array}{l}\text { Respiratorbehandlet } \\
(\mathbf{n = 9})\end{array}$ \\
\hline Alder (år) & $58,9(57 ; 30-90)$ & $73,3(76 ; 42-95)$ & $68,3(74 ; 43-81)$ \\
\hline Menn, antall (\%) & $12(50)$ & $24(60)$ & $7(78)$ \\
\hline $\begin{array}{l}\text { Clinical Frailty Scale- } \\
\text { skår }{ }^{1}\end{array}$ & $2,3(1,5 ; 1-7)$ & $3,8(3,5 ; 1-7)$ & $3,0(3 ; 0-5)$ \\
\hline $\begin{array}{l}\text { Charlson Comorbidity } \\
\text { Index-skår }\end{array}$ & $2,2(1,5 ; 0-9)$ & $4,2(3,5 ; 0-14)$ & $6(67)$ \\
\hline $\begin{array}{l}\geq 1 \text { komorbide tilstander, } \\
\text { antall (\%) }\end{array}$ & $14(58)$ & $26(65)$ & \\
\hline $\begin{array}{l}\text { Komplikasjoner, antall } \\
\text { (\%) }\end{array}$ & & & \\
\hline
\end{tabular}




\begin{tabular}{|c|c|c|c|}
\hline & $\begin{array}{l}\text { Ikke } \\
\text { oksygenbehandlet } \\
(\mathrm{n}=24)\end{array}$ & $\begin{array}{l}\text { Oksygenbehandlet } \\
(n=40)\end{array}$ & $\begin{array}{l}\text { Respiratorbehandlet } \\
(\mathbf{n}=9)\end{array}$ \\
\hline $\begin{array}{l}\text { Symptomer på } \\
\text { delirium }\end{array}$ & $6(25)$ & $16(40)$ & $4(44)$ \\
\hline $\begin{array}{l}\text { Venøs } \\
\text { tromboembolisme }\end{array}$ & $1(4)$ & $2(5)$ & $2(22)$ \\
\hline Kardial påvirkning & $1(4)$ & $9(23)$ & $5(56)$ \\
\hline Akutt nyresvikt & $2(8)$ & $2(5)$ & $4(44)$ \\
\hline Hjerneinfarkt & $1(4)$ & $0(0)$ & $1(11)$ \\
\hline $\begin{array}{l}\text { Bakteriell } \\
\text { superinfeksjon }\end{array}$ & $2(8)$ & $3(8)$ & $6(67)$ \\
\hline Soppinfeksjon & $0(0)$ & $2(5)$ & $7(78)$ \\
\hline \multicolumn{4}{|l|}{ Behandling } \\
\hline $\begin{array}{l}\text { Dager med } \\
\text { oksygenbehandling }\end{array}$ & - & $8,2(8 ; 1-24)$ & $18,6(21 ; 2-31)$ \\
\hline $\begin{array}{l}\text { Dager med } \\
\text { respiratorbehandling }\end{array}$ & - & - & $16,0(18 ; 2-25)$ \\
\hline $\begin{array}{l}\text { Dialyse (prisma), } \\
\text { antall (\%) }\end{array}$ & $0(0)$ & $0(0)$ & $2(22)$ \\
\hline Mageleie, antall (\%) & - & - & $5(55)$ \\
\hline \multicolumn{4}{|l|}{ Laboratorieverdier } \\
\hline $\mathrm{CRP}(\mathrm{mg} / \mathrm{l})^{3}$ & $52(28 ; 3-168)$ & $144(137,5 ; 4-432)$ & $260(257 ; 173-340)$ \\
\hline Lymfocytter $\left(\cdot 10^{9} / \mathrm{I}\right)^{4}$ & $1,1(1,0 ; 0,1-2,9)$ & $0,8(0,6 ; 0,2-2,9)$ & $0,5(0,5 ; 0,3-1,0)$ \\
\hline $\begin{array}{l}\text { Trombocytter }(\cdot \\
\left.10^{9} / 1\right)^{4}\end{array}$ & $194(179,5 ; 118-340)$ & $168(154 ; 50-335)$ & $144(130 ; 68-243)$ \\
\hline Kreatinin $(\mu \mathrm{mol} / \mathrm{I})^{3}$ & $89(74,5 ; 46-209)$ & $94(85 ; 18-266)$ & $144(99 ; 73-247)$ \\
\hline D-dimer (mg/I FEU) $)^{3,5}$ & $0,6(0,5 ; 0,3-1,5)$ & $3,6(1,2 ; 0,2-35,2)$ & $19,1(21,8 ; 0,5-35,2)$ \\
\hline Ferritin $(\mu \mathrm{g} / \mathrm{I})^{3,6}$ & $746(508 ; 28-3656)$ & $\begin{array}{r}1113(859 ; 106-3 \\
453)\end{array}$ & $\begin{array}{r}2754(2197 ; 1525-5 \\
603)\end{array}$ \\
\hline Troponin T $(\mathrm{ng} / \mathrm{l})^{3,7}$ & $13(6 ; 5-60)$ & $53(24 ; 5-590)$ & $545(48 ; 20-3960)$ \\
\hline NT-proBNP (ng/I) & $169(78 ; 35-526)$ & $\begin{array}{r}3770(1310 ; 35-33 \\
250)\end{array}$ & 1333 (1 205; 913-2 010) \\
\hline $\operatorname{ALAT}(U / I)^{3,9}$ & $84(41 ; 18-654)$ & $98(55 ; 12-477)$ & $172(162,5 ; 46-333)$ \\
\hline Sykehusopphold (dager) & $5,8(4 ; 2-14)$ & $10,2(10 ; 2-27)$ & $21,3(21 ; 3-39)$ \\
\hline Intensivavdeling (dager) & - & - & $16,3(18 ; 2-27)$ \\
\hline $\begin{array}{l}\text { Død under } \\
\text { sykehusopphold, antall } \\
\text { (\%) }\end{array}$ & $0(0)$ & $9(23)$ & $5(56)$ \\
\hline $\begin{array}{l}\text { Utskrevet til sykehjem, } \\
\text { antall (\%) }\end{array}$ & $4(17)$ & 7 (18) & 1 (11) \\
\hline
\end{tabular}


${ }^{1}$ Basert på pasientens funksjonsnivå 14 dager før akutt sykdom.

${ }^{2}$ Inkluderer hypertensjon, diabetes mellitus, hjertesykdommer, kronisk nyresykdom, maligne sykdommer, kronisk obstruktiv lungesykdom og andre.

${ }^{3}$ Høyeste verdi i løpet av sykehusoppholdet.

${ }^{4}$ Laveste verdi i løpet av sykehusoppholdet.

${ }^{5}$ Mangler hos 8 pasienter.

${ }^{6}$ Mangler hos 9 pasienter.

${ }^{7}$ Mangler hos 21 pasienter.

${ }^{8}$ Mangler hos 33 pasienter.

${ }^{9}$ Mangler hos 3 pasienter.

Akutt forvirring før innleggelse ble rapportert hos 11 pasienter (15\%). I alt 26 pasienter (36\%) hadde symptomer på delirium under sykehusoppholdet, hvorav 18 (25\%) oppfylte alle kriteriene for delirium. Blant pasienter med alder $\leq 75$ år hadde $12(27 \%)$ delirium, mens 14 pasienter eldre enn 75 år (48\%) hadde delirium. Tabell 2 viser utvalgte karakteristika, funn og forløp for pasienter med og uten symptomer på delirium.

\section{Tabell 2}

Pasienter med og uten delirium innlagt ved Bærum sykehus med covid-19 i perioden 9.3.2020-7.5.2020, $\mathrm{n}=73$. Gjennomsnitt (median; spredning) dersom annet ikke er angitt. $\left(\mathrm{NEWS}_{2}=\right.$ National Early Warning Score 2.)

\begin{tabular}{|lrr|}
\hline & \multicolumn{1}{c}{$\begin{array}{l}\text { Pasienter med } \\
\text { delirium } \\
(\mathbf{n = 2 6})\end{array}$} & $\begin{array}{l}\text { Pasienter uten } \\
\text { delirium } \\
(\mathbf{n}=\mathbf{4 7})\end{array}$ \\
\hline Alder (år) & $72,7(77,5 ; 34-94)$ & $65,3(68 ; 30-95)$ \\
\hline Menn, antall (\%) & $18(69)$ & $25(53)$ \\
\hline Clinical Frailty Scale-skår ${ }^{2}$ & $3,8(4 ; 1-7)$ & $2,6(2 ; 1-7)$ \\
\hline Charlson Comorbidity Index-skår & $4,7(4,5 ; 0-10)$ & $2,7(2 ; 0-14)$ \\
\hline Demens, antall (\%) & $3(12)$ & $2(4)$ \\
\hline Kliniske funn ved innkomst, antall (\%) & $14(54)$ & $15(32)$ \\
\hline NEWS2-skår $\geq 5$ & $9(35)$ & $11(23)$ \\
\hline Hypoksemi (SaO $2 \leq 93 \%)$ & $1(4)$ & $2(4)$ \\
\hline Systolisk blodtrykk < 100 mm Hg & $12,0(10 ; 3-39)$ & $9,1(9 ; 2-28)$ \\
\hline Sykehusopphold (dager) & $8(31)$ & $6(13)$ \\
\hline Død under sykehusopphold, antall (\%) & $8(31)$ & $5(11)$ \\
\hline Utskrevet til sykehjem, antall (\%) & & \\
\hline
\end{tabular}

${ }^{1}$ Inkluderer både sikkert delirium og subsyndromalt delirium.

${ }^{2}$ Basert på pasientens funksjonsnivå 14 dager før akutt sykdom. 
Akutt nyresvikt ble påvist hos åtte pasienter (11\%), hvorav fem døde. Lungeembolisme ble påvist hos fire pasienter, mens én hadde dyp venetrombose. Tre av pasientene med

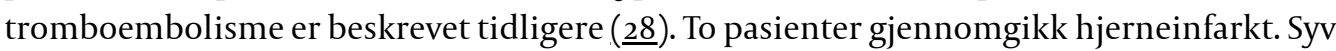
pasienter hadde økt nivå av troponin T samt EKG-funn eller symptomer som tilfredsstilte kriterier for hjerteinfarkt.

\section{Diskusjon}

De fleste pasientene innlagt på sykehus med covid-19 hadde behov for oksygenbehandling, og varigheten av hypoksemi så ut til å være hovedforklaringen på det høye

gjennomsnittlige antallet liggedøgn på sykehus. Én av fire pasienter hadde et svært alvorlig sykdomsforl $\emptyset$, noe som er en litt større andel enn den vi så blant de 42 første pasientene (5). Dødeligheten var høy (19\%), men noe lavere enn i studier fra USA og Storbritannia (preprint), hvor man har funnet en dødelighet i sykehus på 20-35\% (4, 27.). Den høye sykehusdødeligheten i internasjonale studier kan ha en rekke årsaker, blant annet sosioøkonomiske forhold, høy sykelighet i befolkningen, innleggelsesrate og overbelastning av helsevesenet. Vi er ikke kjent med at det er publisert tall for dødelighet fra andre norske sykehus, men det er grunn til å forvente at slike tall kan sprike, blant annet på grunn av ulik alderssammensetning i pasientgruppene og forskjeller i innleggelsespraksis. Vi tror den viktigste grunnen til den høye dødeligheten i vår populasjon er alderssammensetningen. Gjennomsnittsalderen blant pasientene som døde, var nesten 80 år. Et flertall var sårbare eller skrøpelige, noen ble innlagt fra sykehjem, og de fleste som døde, ble ikke behandlet med respirator. Ingen av pasientene med alder over 75 år som ble behandlet med respirator, overlevde. Kun fire av ni intensivpasienter overlevde, til tross for at det blant annet ble gitt omfattende organstøtte med langvarig invasiv respiratorbehandling. Dersom det var nødvendig, ble pasientene også periodevis lagt i bukleie og curarisert for optimalisert gassutveksling. Sirkulasjonsstøtte ble gitt med vekt på å unngå overvæsking, og nyreerstattende terapi ble gitt til to av ni intensivpasienter.

Når en samlet vurdering tilsa det, ble begrensning av intensivbehandling besluttet basert på pasientens $\emptyset$ nske (28) $)$, alvorlighetsgraden av den akutte sykdommen, komorbiditetsbyrde (29). og premorbid funksjonssnivå (frailty) (30,, 31 ).

Én av tre pasienter hadde symptomer på delirium. Forekomsten er sammenlignbar med

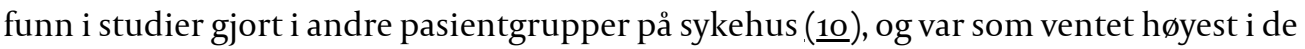
eldste aldersgruppene. Andelen med delirium blant intensivpasientene var lavere enn i studier av intensivpasienter med andre sykdommer (111). Diagnosekriteriene for delirium omfatter ikke symptomer på økt sympatikusaktivitet som for eksempel takykardi, mydriasis og svetting. Noen tilfeller av delirium kan ha blitt oversett blant pasienter som ble sedert og intubert kort tid etter innleggelse, og som ikke våknet igjen. Anestetika og andre medikamenter brukt under intensivbehandlingen kan ha påvirket forekomsten av delirium. De fleste pasientene med delirium hadde hyperaktive symptomer. Symptomer på hypoaktivt delirium overses oftere, og vi kan ikke utelukke at forekomsten av delirium er underestimert. Kun tilfeller hvor det forelå tydelig dokumentasjon av endring i kognitiv funksjon, bevissthet eller oppmerksomhet basert på opplysninger fra pårørende eller helsepersonell, ble klassifisert som akutt forvirring, delirium eller subsyndromalt delirium. I andre pasientgrupper er det godt dokumentert at tidlig oppdagelse av delirium og ikke-medikamentelle tiltak kan bedre prognosen (32), og det geriatriske fagmiljøet i Norge har tidligere tatt til orde for å innføre systematisk deliriumscreening blant pasienter innlagt på sykehus (33), for eksempel ved hjelp av screeningverktøyet 4AT. Dette verktøyet er enkelt og tar kort tid å bruke, men opplæring er nødvendig for å oppnå god kvalitet (34). Den høye forekomsten av symptomer på delirium i vår studie støtter en slik anbefaling. Kognitiv svikt og delirium kan være særlig utfordrende hos pasienter som må isoleres for å 
hindre smittespredning (35). Man kan tenke seg at både langvarig isolasjon fra pårørende og bruk av smittevernutstyr som munnbind blant omsorgspersoner kan virke negativt på en pasient med delirium.

Det er rapportert $\emptyset \mathrm{kt}$ forekomst av venøse og arterielle tromboemboliske komplikasjoner hos covid-19-pasienter på grunn av økt trombogenisitet (36,.37.). I vår studie hadde syv pasienter tromboembolisme; tre av disse er tidligere presentert (3요). Det faktiske antallet kan ha vært høyere ettersom radiologiske undersøkelser kun ble utført ved klinisk mistanke. Våre funn, som er i tråd med tidligere publikasjoner (37.), støtter bruk av tromboseprofylakse hos covid-19-pasienter innlagt i sykehus og taler for at terskelen bør være lav for supplerende billeddiagnostikk ved kliniske tegn på tromboemboliske komplikasjoner.

Ved influensalignende sykdom er alvorlige sykdomsforløp ofte assosiert med bakteriell superinfeksjon (39), og det har blitt spekulert på om den høye dødeligheten blant pasienter med covid-19 i middelhavsområdene i Europa delvis kan skyldes superinfeksjoner med multiresistente mikrober ( $4 \underline{\text { o }}$ ). Superinfeksjoner forekom sjelden i vårt materiale og så ut til å ha liten betydning for pasientforløpene. Vanligst var mikrobiologiske funn i luftveier, mens det kun var én positiv blodkultur. Dette er i overensstemmelse med rapporter fra Europa, USA og Kina (41-43). En høy andel av våre pasienter fikk doksysyklin for å utnytte medikamentets immunmodulerende egenskaper (44.). Dette kan tenkes å ha hatt en forebyggende effekt mot bakterielle sekundærinfeksjoner. Det ble imidlertid ikke gitt profylaktisk antibiotikabehandling.

Mange pasienter med covid-19 har høy feber og er utsatt for væsketap. Likevel var akutt nyresvikt i henhold til RIFLE-kriteriene relativt sjeldent og forekom hovedsakelig blant intensivpasientene eller pasienter som døde.

Hovedstyrken med vår studie er at den er utført ved et stort lokalsykehus, og at samtlige pasienter som ble innlagt og utskrevet i løpet av de første 6o dagene av det lokale utbruddet i Asker og Bærum, ble inkludert i studien. Studiens prospektive design reduserer risiko for feil og mangler, men utelukker ikke at manglende dokumentasjon kan ha påvirket resultatene. Den største svakheten ved studien er det relativt lave antallet pasienter, som gjør at funnene må tolkes med varsomhet. Så langt vi kjenner til, er det til nå ikke publisert studier utført blant pasienter innlagt med covid-19 ved andre norske sykehus. Vi tror våre funn har overføringsverdi både til andre lokalsykehus og til framtidige pasienter ved vårt eget sykehus, og funn fra studien brukes allerede i sykehusets kvalitetsforbedringsarbeid.

\section{Konklusjon}

Dødelighet blant pasienter med covid-19 innlagt på et norsk lokalsykehus var 19\%. De fleste som døde, var over 75 år og skrøpelige og ble ikke behandlet med respirator. Et flertall av de innlagte pasientene hadde behov for langvarig oksygenbehandling. Delirium forekom hos én av tre pasienter og var den vanligste ikke-respiratoriske komplikasjonen.

Artikkelen er fagfellevurdert.

LITTERATUR

1. Wu F, Zhao S, Yu B et al. A new coronavirus associated with human respiratory disease in China. Nature 2020; 579: 265-9. [PubMed][CrossRef] 
2. World Health Organization. Coronavirus disease 2019 (COVID-19): situation report, 51. https://www.who.int/docs/default-source/coronaviruse/situation-reports/20200311-sitrep-51-covid19.pdf?sfvrsn=1ba62e57_10 Lest 20.3.2020.

3. Folkehelseinstituttet. Covid-19-epidemien: Kunnskap, situasjon, prognose, risiko og respons i Norge etter uke 18. https://www.fhi.no/contentassets/c9e459cd7cc24991810aod28d7803bdo/notat-omrisiko-og-respons-2020-05-05.pdf Lest 5.5.2020.

4. Richardson S, Hirsch JS, Narasimhan M et al. Presenting characteristics, comorbidities, and outcomes among 5700 patients hospitalized with COVID-19 in the New York City Area. JAMA 2020; 323: 2052. [PubMed][CrossRef]

5. Ihle-Hansen H, Berge T, Tveita A et al. Covid-19: Symptomer, forløp og bruk av kliniske skåringsverktøy hos de 42 første pasientene innlagt på et norsk lokalsykehus. Tidsskr Nor Legeforen 2020; 140. doi: 10.4045/tidsskr.20.0301. [PubMed][CrossRef]

6. Guan WJ, Ni ZY, Hu Y et al. Clinical characteristics of coronavirus disease 2019 in China. N Engl J Med 2020; 382: 1708-20. [PubMed][CrossRef]

7. Neerland BE, Dobloug A, Nore KG et al. Covid-19 påvist hos eldre kvinne med akutt funksjonssvikt. Tidsskr Nor Legeforen 2020; 140. doi: 10.4045/tidsskr.20.0307. [PubMed][CrossRef]

8. Hjelmesæth J, Skaare D. Covid-19 med nedsatt lukte- og smakssans som eneste symptom. Tidsskr Nor Legeforen 2020; 140. doi: 10.4045/tidsskr.20.0287. [PubMed][CrossRef]

9. Sellevoll HB, Saeed U, Young VS et al. Covid-19 med akutte magesmerter som debutsymptom. Tidsskr Nor Legeforen 2020;140. doi: 10.4045/tidsskr.20.0262. [PubMed][CrossRef]

10. Pendlebury ST, Lovett NG, Smith SC et al. Observational, longitudinal study of delirium in consecutive unselected acute medical admissions: age-specific rates and associated factors, mortality and re-admission. BMJ Open 2015; 5: eoo7808. [PubMed][CrossRef]

11. Ely EW, Shintani A, Truman B et al. Delirium as a predictor of mortality in mechanically ventilated patients in the intensive care unit. JAMA 2004; 291: 1753-62. [PubMed][CrossRef]

12. Inouye SK, Westendorp RG, Saczynski JS. Delirium in elderly people. Lancet 2014;383: 911-22. [PubMed][CrossRef]

13. Poissy J, Goutay J, Caplan M et al. Pulmonary embolism in COVID-19 patients: Awareness of an increased prevalence. Circulation 2020; 141. doi:10.1161/CIRCULATIONAHA.120.047430. [PubMed] [CrossRef]

14. Helms J, Kremer S, Merdji H et al. Neurologic features in severe SARS-CoV-2 infection. N Engl J Med 2020;382: 2268-70. [PubMed][CrossRef]

15. Morens DM, Taubenberger JK, Fauci AS. Predominant role of bacterial pneumonia as a cause of death in pandemic influenza: implications for pandemic influenza preparedness. J Infect Dis 2008; 198: 962-70. [PubMed][CrossRef]

16. Wu Z, McGoogan JM. Characteristics of and important lessons from the coronavirus disease 2019 (COVID-19) outbreak in China: Summary of a report of 72314 cases from the Chinese center for disease control and prevention. JAMA 2020;323: 1239-42. [PubMed][CrossRef]

17. Statistisk sentralbyrå (SSB). Befolkning og kvartalsvise endringar, etter region, statistikkvariabel og kvartal. https://www.ssb.no/statbank/table/01222 Lest 15.6.2020.

18. Charlson ME, Pompei P, Ales KL et al. A new method of classifying prognostic comorbidity in longitudinal studies: development and validation. J Chronic Dis 1987; 40:373-83. [PubMed][CrossRef]

19. Rockwood K, Song X, MacKnight C et al. A global clinical measure of fitness and frailty in elderly people. CMAJ 2005; 173: 489-95. [PubMed][CrossRef]

20. Diagnostic and Statistical Manual of Mental Disorders 5 (DSM-5) Classification. Washington, DC: American Psychiatric Association, 2013. https://www.psychiatry.org/psychiatrists/practice/dsm Lest 15.6.2020.

21. Kuhn E, Du X, McGrath K et al. Validation of a consensus method for identifying delirium from hospital records. PLoS One 2014; 9: e111823. [PubMed][CrossRef]

22. Inouye SK, Leo-Summers L, Zhang Y et al. A chart-based method for identification of delirium: validation compared with interviewer ratings using the confusion assessment method. J Am Geriatr Soc 2005; 53:312-8. [PubMed][CrossRef]

23. Roffi M, Patrono C, Collet JP et al. 2015 ESC Guidelines for the management of acute coronary syndromes in patients presenting without persistent ST-segment elevation: Task Force for the Management of Acute Coronary Syndromes in Patients Presenting without Persistent ST-Segment Elevation of the European Society of Cardiology (ESC). Eur Heart J 2016; 37: 267-315. [PubMed] [CrossRef] 
24. Kirchhof P, Benussi S, Kotecha D et al. 2016 ESC Guidelines for the management of atrial fibrillation developed in collaboration with EACTS. Eur Heart J 2016; 37: 2893-962. [PubMed] [CrossRef]

25. Sacco RL, Kasner SE, Broderick JP et al. An updated definition of stroke for the 21st century: a statement for healthcare professionals from the American Heart Association/American Stroke Association. Stroke 2013; 44: 2064-89. [PubMed][CrossRef]

26. Bellomo R, Ronco C, Kellum JA et al. Acute renal failure - definition, outcome measures, animal models, fluid therapy and information technology needs: the Second International Consensus Conference of the Acute Dialysis Quality Initiative (ADQI) Group. Crit Care 2004; 8: R204-12. [PubMed][CrossRef]

27. Docherty AB, Harrison EM, Green CA et al. Features of 16,749 hospitalised UK patients with COVID19 using the ISARIC WHO Clinical Characterisation Protocol. medRxiv.

https://www.medrxiv.org/content/10.1101/2020.04.23.20076042v1 Lest 15.6.2020.

28. White DB, Braddock CH, Bereknyei S et al. Toward shared decision making at the end of life in intensive care units: opportunities for improvement. Arch Intern Med 2007; 167: 461-7. [PubMed] [CrossRef]

29. Morland M, Haagensen R, Dahl FA et al. Epidemiologi og prognoser i en medisinsk overvåkningsavdeling. Tidsskr Nor Legeforen 2018; 138. doi: 10.4045/tidsskr.17.0496. [PubMed] [CrossRef]

30. Guidet B, de Lange DW, Boumendil A et al. The contribution of frailty, cognition, activity of daily life and comorbidities on outcome in acutely admitted patients over 80 years in European ICUs: the VIP2 study. Intensive Care Med 2020; 46: 57-69. [PubMed][CrossRef]

31. Covinsky KE, Palmer RM, Counsell SR et al. Functional status before hospitalization in acutely ill older adults: validity and clinical importance of retrospective reports. J Am Geriatr Soc 2000; 48: 1649. [PubMed][CrossRef]

32. Hshieh TT, Yue J, Oh E et al. Effectiveness of multicomponent nonpharmacological delirium interventions: a meta-analysis. JAMA Intern Med 2015; 175: 512-20. [PubMed][CrossRef]

33. Evensen S, Saltvedt I, Ranhoff AH et al. Delirium og kognitiv svikt blant eldre i norske akuttmottak. Tidsskr Nor Legeforen 2019; 140. doi:10.4045/tidsskr.18.057. [CrossRef]

34. Myrstad M, Watne LO, Johnsen NT et al. Delirium screening in an acute geriatric ward by nurses using 4AT: results from a quality improvement project. Eur Ger Med 2019; 10: 667-71. [CrossRef]

35. Neerland BE, Watne LO, Krogseth M. Delirium hos pasienter med covid-19. Tidsskr Nor Legeforen 2020; 140. doi: 10.4045/tidsskr.20.0264. [PubMed][CrossRef]

36. Klok FA, Kruip MJHA, van der Meer NJM et al. Incidence of thrombotic complications in critically ill ICU patients with COVID-19. Thromb Res 2020;191: 145-7. [PubMed][CrossRef]

37. Lodigiani C, Iapichino G, Carenzo L et al. Venous and arterial thromboembolic complications in COVID-19 patients admitted to an academic hospital in Milan, Italy. Thromb Res 2020; 191: 9-14. [PubMed][CrossRef]

38. Tveita A, Hestenes S, Sporastøyl ER et al. Lungeembolisme ved covid-19. Tidsskr Nor Legeforen 2020; 140. doi: 10.4045/tidsskr.20.0366. [PubMed][CrossRef]

39. Blyth CC, Webb SA, Kok J et al. The impact of bacterial and viral co-infection in severe influenza. Influenza Other Respir Viruses 2013; 7: 168-76. [PubMed][CrossRef]

40. Martiniussen E. Derfor tar koronaviruset så mange liv i Italia. Aftenposten 24.3.2020.

https://www.aftenposten.no/meninger/kronikk/i/awEP27/derfor-tar-koronaviruset-saa-mange-liv-iitalia-erik-martiniussen Lest 24.3.2020.

41. Zhou F, Yu T, Du R et al. Clinical course and risk factors for mortality of adult inpatients with COVID-19 in Wuhan, China: a retrospective cohort study. Lancet 2020;395:1054-62. [PubMed] [CrossRef]

42. Goyal P, Choi JJ, Pinheiro LC et al. Clinical characteristics of covid-19 in New York City. N Engl J Med 2020;382: 2372-4. [PubMed][CrossRef]

43. European Centre for Disease Prevention and Control. Coronavirus disease 2019 (COVID-19) pandemic: increased transmission in the EU/EEA and the UK - seventh update. https://www.ecdc.europa.eu/sites/default/files/documents/RRA-seventh-update-Outbreak-ofcoronavirus-disease-COVID-19.pdf Lest 25.3.2020.

44. Bensman TJ, Nguyen AN, Rao AP et al. Doxycycline exhibits anti-inflammatory activity in CF bronchial epithelial cells. Pulm Pharmacol Ther 2012; 25:377-82. [PubMed][CrossRef] 
Publisert: 24. juni 2020. Tidsskr Nor Legeforen. DOI: 10.4045/tidsskr.20.0432

Mottatt 13.5.2020, første revisjon innsendt 27.5.2020, godkjent 7.6.2020.

Publisert under åpen tilgang CC BY-ND. Lastet ned fra tidsskriftet.no 26. april 2023. 